\title{
WOOD AND CHARCOAL PRODUCTION IN THE KILN-FURNACE SYSTEM: HOW DO THE COSTS AND REVENUES VARIATION AFFECT ECONOMIC FEASIBILITY?
}

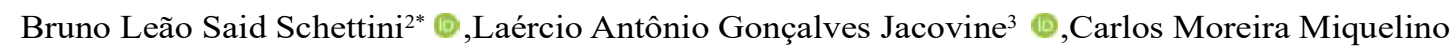
Eleto Torres ${ }^{3} \odot$,Angélica de Cássia Oliveira Carneiro ${ }^{3}$ ๑,Paulo Henrique Villanova ${ }^{\circledR}$,Samuel José Silva Soares da Rocha ${ }^{\circ}$, Maria Paula Miranda Xavier Rufino ${ }^{2}{ }^{\circ}$ and Renato Vinícius Oliveira Castro ${ }^{4}()^{\circ}$

\footnotetext{
${ }^{1}$ Received on 26.05.2021 accepted for publication on 02.09.2021.

${ }^{2}$ Universidade Federal de Viçosa, Programa de Pós-Graduação em Ciência Florestal, Viçosa, MG - Brasil. E-mail: < bruno.schettini@ufv. br>,<paulo.villanova@ufv.br>,<samuel.rocha@ufv.br> and<maria.rufino@ufv.br>.

${ }^{3}$ Universidade Federal de Viçosa, Departamento de Engenharia Florestal, Viçosa, MG - Brasil. E-mail: <jacovine@ufv.br>, <carlos. eleto@ufv.br> and < cassiacarneiro@ufv.br>.

${ }^{4}$ Universidade Federal de São João del-Rei, Departamento de Engenharia Florestal, Sete Lagoas, MG - Brasil. E-mail: <renatocastro@ ufsj.edu.br>.

*Corresponding author.
}

\begin{abstract}
Traditional methods of economic evaluation of wood and charcoal production projects are based on indicators analysis, however, they are subject to market variations and uncertainties. The study was carried out in the city of Lamim, Minas Gerais State, to evaluate the economic viability of wood and charcoal production using the kiln-furnace system, due to the need to know the economic viability of this new production system. Sensitivity analysis using the Monte Carlo technique was performed on costs and revenues. The wood and charcoal production cash flow was elaborated and the following criteria were used in the economic analysis: Net Present Value (NPV), Benefit-Cost Ratio (BCR), Equivalent Periodic Value (EPV), and Internal Return Rate (IRR). The wood and charcoal production sensitivity analysis was carried out using the software @RISK, according to the VPE parameter, which allows comparing projects with different durations. Wood production was economically viable, with NPV of $\$ 40.26 \mathrm{ha}^{-1}$ and EPV of $\$ 16.80 \mathrm{ha}^{-1}$, with an average production cost of $\$ 13.51 \mathrm{~m}^{3}$ wood $^{-1}$. The EPV mean value found in the sensitivity analysis was $\$ 18.33$ $\mathrm{ha}^{-1}$. The charcoal production was economically viable, with NPV of $\$ 4.43 \mathrm{mdc}^{\text {charcoal }}{ }^{-1}$ and EPV of $\$ 3.52$ mdc charcoal ${ }^{-1}$. The EPV mean value found in the sensitivity analysis was $\$ 9.80 \mathrm{mdc}^{\text {charcoal }}{ }^{-1}$. It was possible to conclude that the wood and charcoal production are economically viable in the region.
\end{abstract}

Keywords: Risk analysis, Sensitivity analysis, Sustainable steelmaking.

\section{PRODUÇÃO DE MADEIRA E CARVÃO VEGETAL NO SISTEMA FORNO- FORNALHA: COMO A VARIAÇÃO NOS CUSTOS E RECEITAS AFETAM A VIABILIDADE ECONÔMICA?}

RESUMO - Os métodos tradicionais de avaliação econômica de projetos de produção de madeira e carvão vegetal são baseados na análise de indicadores, porém, estão sujeitas a variações de mercado e incertezas. O estudo foi conduzido no município de Lamim-MG, para avaliação da viabilidade econômica na produção de madeira e carvão vegetal com o uso do sistema forno-fornalha, devido à necessidade de se conhecer a viabilidade econômica desse novo sistema produtivo. A análise de sensibilidade utilizando a técnica de Monte Carlo foi realizada nos custos e receitas. O fluxo de caixa para a produção de madeira e de carvão vegetal foi elaborado e os seguintes critérios foram utilizados na análise econômica: Valor Presente Líquido (VPL), Razão Beneficio Custo (B/C), Valor Periódico Equivalente (VPE) e Taxa Interna de Retorno (TIR). A análise de sensibilidade na produção de madeira e da produção de carvão vegetal foi realizada com o auxílio do software @ RISK, de acordo com o parâmetro VPE, que permite comparar projetos com durações diferentes. A produção de madeira foi viável economicamente, com VPL de R\$212,68 ha e VPE de R\$88,74 ha $\mathrm{h}^{-1}$, com custo médio de produção de $R \$ 71,37 \mathrm{~m}^{3}$ madeira ${ }^{-1}$. O valor médio do VPE encontrado na análise de sensibilidade foi de $R \$$ $96,82 \mathrm{ha}^{-1}$. A produção de carvão vegetal foi viável economicamente, com VPL de $R \$ 23,41 \mathrm{mdc}^{\text {carvão vegetal }}{ }^{-1}$

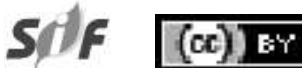

Revista Árvore 2021;45:e4539 http://dx.doi.org/10.1590/1806-908820210000039 
e VPE de R\$18,57 mdc carvão vegetal ${ }^{-1}$. O valor médio do VPE encontrado na análise de risco foi de $R \$ 51,78$ mdc carvão vegetal ${ }^{-1}$. Foi possivel concluir que a produção de madeira de eucalipto e de carvão vegetal são viáveis economicamente na região.

Palavras-Chave: Análise de risco; Análise de sensibilidade; Siderurgia sustentável.

\section{INTRODUCTION}

Brazil is the largest charcoal producer and consumer in the industry in the world, with pig iron and ferro-alloy steel industries responsible for consuming $84 \%$ of the total available. The brazilian charcoal consumption in 2018, in the steel sector, was 4.6 million tons and, Minas Gerais State was the main producer. Commercial forests, mostly eucalypt plantations, are the main raw material used in the charcoal sector in the country, with a total of $91 \%$ (IBÁ, 2020).

Small rural producers are responsible for approximately $80 \%$ of the brazilian charcoal production (Oliveira et al., 2013) in a carbonization process done, mostly, in rudimentary masonry kilns, "hot-tailed" and surface type, with low gravimetric yield (GY) and no greenhouse gas (GHG) emissions control (Costa et al., 2019). The replacement of these rudimentary systems by technological systems is a challenge in the sector, for requiring greater investments, that would increase carbonization costs, and may inhibit the adoption by small and medium producers (Vilela et al., 2014; Ribeiro et al., 2020). The charcoal price variation over the years, the technologies used in production and environmental issues are considered the main problems in the sector in Brazil (Cardoso et al., 2010).

The United Nations Development Program (UNDP) implemented the Sustainable Steel Project to improve the Brazilian charcoal production process, after the commitments assumed by the government to reduce GHG emissions in the Paris Agreement. The project encourages innovative and more efficient technologies and productive arrangements for the charcoal production from planted forests in the Brazilian steel industry. The Sustainable Steel Project was designed to improve charcoal production efficiency with the least possible impact on GHG emissions (ONU, 2018).

Within the Sustainable Steel Project, the kilnfurnace system was developed. This system allows the GHG burning, with an innovative layout that has a centralized furnace with 4 kilns, and that allows the increase of the GY when compared with the traditional kilns (Oliveira et al., 2017). Despite being a viable carbonization alternative compared to traditional models, for being technically and environmentally viable, there are still questions about the kiln-furnace system economic viability (Oliveira et al., 2014). This is because "hot-tail" kilns, which are the most used in Brazil, despite being simple and with low GY, are economically viable, which makes the business attractive to rural producers and helps supply industrial demand (Silva et al., 2014). Thus, economic viability studies of charcoal production in this new arrangement are necessary, to encourage the new technology adoption by rural producers (Oliveira et al., 2015).

Economic analysis traditional methods in charcoal production are based on indicators analysis, although, as well in forestry activities, since they are long-term, they are subject to market variations and uncertainties (Oliveira et al., 2017), due to the product price fluctuation over the years (Oliveira et al., 2013). These studies make the economic evaluation jointly, that is, the same economic indicator represents wood and charcoal production viability, not being able to assess which of the two products impact the project the most, positively and/or negatively.

Monte Carlo simulation can be used to assess risk in decision making, for allowing the performance of a variable to be observed due to the behavior of other (Zarony et al., 2019). The Monte Carlo method is used to numerically operate systems that have random components, several simulations are carried out and, in each of them, random values are generated for the variables subject to uncertainty input, with previously determined distributions. At the end of the simulation, results are generated based on random values and the probabilities of their occurrence (Yang et al., 2020).

The study was conducted on a rural property in the city of Lamim Minas Gerais State, with the goal of economic viability evaluating in the wood and

Revista Árvore 2021;45:e4539 
charcoal production, and how the costs and revenues variation can impact this result, through risk analysis using the Monte Carlo technique.

\section{MATERIAL AND METHODS}

\subsection{Site characterization}

The study was conducted on a charcoal farm in Lamim, State of Minas Gerais, Brazil (2047'08.56" $\mathrm{S}$ and $43^{\circ} 26^{\prime} 37.78^{\prime \prime} \mathrm{O}$ ), in the Zona da Mata Area (Figure 1). The charcoal is produced from a hybrid of Eucalyptus grandis $\mathrm{x}$ Eucalyptus urophylla, planted at a spacing of $3.0 \mathrm{~m} \times 2.0 \mathrm{~m}$, in 20.05 ha, in mountainous region, and low use of technology in wood production. According to the Köppen, the climate of the region is Cwa, i.e.subtropical with dry winter and hot and rainy summer (Rolim et al., 2007). Precipitation occurs mainly between October and March, with averages of 1,435 $\mathrm{mm}$ per year. June and July present the lowest temperatures $\left(12^{\circ} \mathrm{C}\right)$, and January the highest temperatures $\left(25^{\circ} \mathrm{C}\right)$. Data were collected from January 2018 to January 2019.

The farm is characterized by charcoal production for the steel industry, with family labor, in the LamimMG region. The dystrophic red-yellow Oxisol

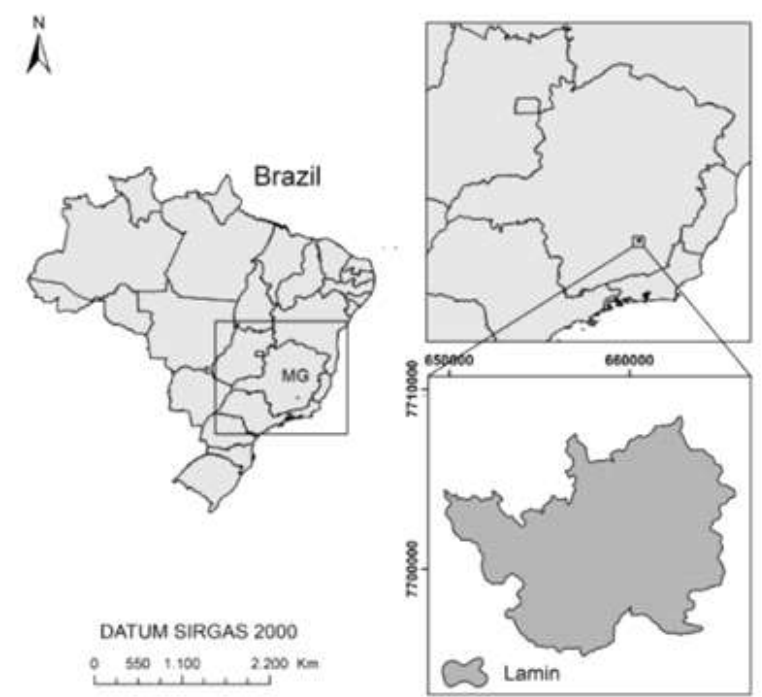

Figure 1 - Farm in Lamim-MG, which the inventory was conducted to volume, biomass and carbon estimate.

Figura 1 - Fazenda em Lamim-MG, onde foi conduzido o inventário florestal para estimativa de biomassa, volume e carbono. predominates in the city of Lamim-MG, as well as in most of the Zona da Mata region.

\subsection{Forest Inventory}

Simple casual sampling was carried out in the forest inventory, with 27 sample units of $300 \mathrm{~m}^{2}(20 \mathrm{x}$ $15 \mathrm{~m})$. The circunference at breast height (cbh) of all trees was measured, converted to diameter at breast height (dbh) and separated into diametric classes with an amplitude of $2.5 \mathrm{~cm}$. The total height of all trees present in the sample units was measured using the equipment Vertex IV®. The equation for estimating the wood volume present in the stem was based on the model by Schumacher \& Hall (1933) and presented an appropriate adjustment, with the following results:

$$
\begin{gathered}
\mathrm{Vcc}=0,00008778 * d b h^{1,472} * \mathrm{Th}^{1,262} \\
\mathrm{R}_{2 \mathrm{adj}}=98,56 \% ; \text { Bias }=-0,12 \%
\end{gathered}
$$

Eq. 1

The Average Annual Volume Increment (AAVI) used in the economic analysis was $26 \mathrm{~m} 3 \mathrm{ha}^{-1}$ year $^{-1}$, at 7 years old, in the first rotation and $23,4 \mathrm{~m}^{3} \mathrm{ha}^{-1}$ year- 1 in the second rotation.

\subsection{Wood carbonization}

The kiln-furnace system is composed of 4 circular surface kilns and a furnace connected to them by ducts, which has a combustion chamber, where the burning of carbonization gases is carried out (Figure 2). Each kiln has a volumetric capacity of approximately 9.0

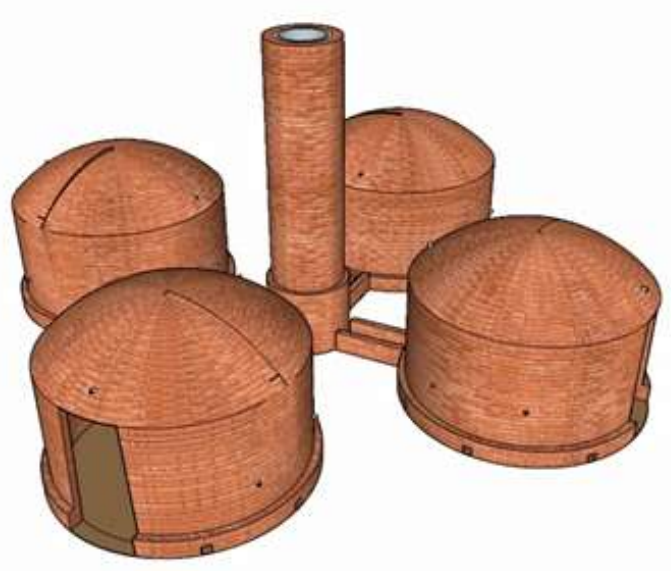

Figure 2 - Furnace-kiln system used in rural properties, for the charcoal production.

Figura 2 - Sistema forno-fornalha usado em propriedades rurais, para produção de carvão vegetal.

\author{
Revista Árvore 2021;45:e4539
}


m3 of wood, value obtained by checking the weight in three kiln loads. The wood moisture entrance in the kilns was $35.00 \%$ and the GY found was $32.76 \%$. The temperature control is done by opening and closing the air controllers (6 per kiln)that are arranged on the bottom of the walls of the kilns. Each kiln has 4 metal wells distributed between the top and the walls, which allow the measurement of temperature. These temperature measurements were determined by an infrared sensor, pyrometer, model MT-350®, with measurement capability between $30-550^{\circ} \mathrm{C}$.

Carbonization was divided into stages, for better process control. The 4 kilns cannot operate simultaneously in phases III and IV due to the high temperature and risk of the furnace giving way, so 2 layouts are required.

\subsection{Costs and revenues composition}

Wood production was analyzed separately from the charcoal production. The costs and revenues used were based on data collection during the monitoring period, rural producers information and municipality environmental agencies.

\subsubsection{Wood production}

The Eucalypt plantation area considered for the economic analysis was 20.05 ha and the costs were separated into the following groups:

- Area preparing: Area cleaning, marking planting lines, marking pits and dimpling, building and maintaining firebreaks.

- Planting: Eucalypt seedlings, fertilizers (NPK), purified MAP, pre and post-emergent herbicide and its application, insecticide bait and its application, termite, transport of inputs, pit fertilization, planting and replanting.

- Harvesting and transportation: Cutting, twisting, bucketing, loading and transport.

- Machines: Chainsaw, motor scooter and tractor.

- Land cost (land value multiplied by interest rate).

Eucalypt cultivation in the region is usually commercialized in two productive cycles. The wood sale was considered in the years 7 and 14, per $\$ 14.20 \mathrm{~m} 3$, a value that is commonly used in the
Lamim-MG region, according to data provided by the timber buyer. The interest rate was $6 \%$ p.a. The labor charges considered were 68\% (Sebrae, 2015). The transportation radius considered for the economic analysis of the sale of wood was $50 \mathrm{~km}$.

\subsubsection{Charcoal production}

Charcoal production costs have been separated into the following groups:

- Labor: Carbonizer, kiln construction, land preparation.

- Kiln items construction cost.

- Kiln maintenance cost (inserted after the second year - $\$ 113,44)$.

- Furnace items construction cost.

- Wood purchase.

- Land cost (land value multiplied by interest rate).

- Furnace maintenance cost (inserted after the second year $-\$ 53,20)$.

- Charcoal transportation.

The carbonization period considered in the charcoal production assessments was 10 years, which is the kiln-furnace service life. The carbonization duration, from the kiln loading to the unloading, was 7.5 days. The charcoal selling price was $\$ 47.32$ mdc charcoal-1, value that is marketed in the region. The charcoal and wood costs of fees and taxes related were not considered in the assessment. The wood consumption by the furnace considered during carbonization, was approximately $100 \mathrm{~kg}$ per carbonization cycle (Oliveira et al., 2014).

\subsection{Economic analysis}

Wood and charcoal production cash flow was prepared and the following criteria were used in the economic analysis:

\subsubsection{Net presente value (NPV)}

NPV is defined as the sum of revenues less costs associated with it. A project is considered economically viable if its NPV is bigger than zero, at a certain interest rate (Rezende e Oliveira, 2013), according to the following equation: 


$$
\mathrm{NPV}=\sum \mathrm{R}_{\mathrm{j}} \div(1+\mathrm{i})^{\mathrm{j}}-\sum \mathrm{C}_{\mathrm{j}} \div(1+\mathrm{i})^{\mathrm{j}}
$$

Where: NPV - net present value; $\mathrm{Rj}$ - revenue at the end of year $\mathrm{j} ; \mathrm{Cj}$ - cost at the end of year j; i - interest rate and $\mathrm{j}$ - cost or revenue period of occurrence.

\subsubsection{Benefit-Cost Ratio (BCR)}

The Benefit-Cost ratio consists of the revenues and costs relationship given project, for a certain interest rate (Rezende e Oliveira, 2013), according to the following equation:

$\mathrm{BCR}=\left(\sum \mathrm{R}_{\mathrm{j}} \div(1+\mathrm{i})^{\mathrm{j}}\right) \div\left(\sum \mathrm{C}_{\mathrm{j}} \div(1+\mathrm{i})^{\mathrm{j}}\right)$

Where: BCR - Benefit-Cost Ratio; $\mathrm{Rj}$ - revenue at the end of year $\mathrm{j} ; \mathrm{Cj}$ - cost at the end of year $\mathrm{j}$; $\mathrm{i}$ interest rate and $\mathrm{j}$ - period of occurrence of the cost or revenue.

\subsubsection{Equivalent Periodic Value (EPV)}

It is defined as the periodic installment that equals the NPV of an investment option to be valued, over the project duration (Rezende e Oliveira, 2013). Calculated according to the following equation:

$$
\mathrm{EPV}=\mathrm{NPV} *\left[(1+\mathrm{i})^{\mathrm{t}}-1\right] \div 1-(1+\mathrm{i})^{-\mathrm{nt}}
$$

Where: NPV - Net Present Value; n - duration of the project, in years; $\mathrm{t}$ - number of capitalization periods, in years; i - interest rate. The project is considered economically viable if the EPV is positive.

\subsubsection{Internal Return Rate (IRR)}

It is the discount rate that equals NPV to zero, that is, present value of revenue equal to present value of costs (Rezende e Oliveira, 2013). Calculated according to the following equation:

$$
\sum \mathrm{R}_{\mathrm{j}}(1+\mathrm{IRR})^{-\mathrm{j}}=\sum \mathrm{C}_{\mathrm{j}}(1+\mathrm{IRR})^{-\mathrm{j}}
$$

Where: $\mathrm{R}$ - Revenues at the end of year $\mathrm{j}$; $\mathrm{C}$ Costs at the end of year $\mathrm{j}$; IRR - Internal return rate; $\mathrm{j}$ - duration of the project, in years. The project will be economically viable when the IRR is higher than the Minimum Attractiveness Rate, which was $2.11 \%$.

\subsection{Risk analysis}

The risk analysis of the wood and charcoal production economic viability was carried out with the

Table 1 - Composition of area preparation costs, planting, harvesting and transport, machinery, land cost, revenue and cash flow.

\begin{tabular}{|c|c|c|c|c|c|c|c|c|}
\hline Year & $\begin{array}{c}\text { Area Preparing } \\
\left(\$ \text { ha }^{-1}\right)\end{array}$ & $\begin{array}{c}\text { Planting } \\
\left(\$ \text { ha }^{-1}\right)\end{array}$ & $\begin{array}{c}\text { Harverting and } \\
\text { Transportation } \\
\qquad\left(\$ \text { ha }^{-1}\right)\end{array}$ & $\begin{array}{c}\text { Machines } \\
\left(\$ \text { ha }^{-1}\right)\end{array}$ & $\begin{array}{c}\text { Land Cost } \\
\left(\$ \mathbf{h a}^{-1}\right)\end{array}$ & $\begin{array}{c}\text { Total Cost } \\
\left(\$ \mathbf{h a}^{-1}\right)\end{array}$ & $\begin{array}{c}\text { Revenue } \\
\left(\$ \text { ha }^{-1}\right)\end{array}$ & $\begin{array}{r}\text { Cash Flow } \\
\left(\$ h^{-1}\right)\end{array}$ \\
\hline $\mathbf{0}$ & 119.82 & 550.59 & 0 & 105.62 & 68.15 & 884.18 & 0 & $-884,18$ \\
\hline 1 & 0 & 35.11 & 0 & 0 & 68.15 & 103.25 & 0 & -103.25 \\
\hline 2 & 0 & 9.75 & 0 & 0 & 68.15 & 77.90 & 0 & -77.90 \\
\hline 3 & 0 & 9.75 & 0 & 0 & 68.15 & 77.90 & 0 & -77.90 \\
\hline 4 & 0 & 9.75 & 0 & 0 & 68.15 & 77.90 & 0 & -77.90 \\
\hline 5 & 0 & 9.75 & 0 & 0 & 68.15 & 77.90 & 0 & -77.90 \\
\hline 6 & 0 & 9.75 & 0 & 0 & 68.15 & 77.90 & 0 & -77.90 \\
\hline 7 & 0 & 9.75 & $1.240,62$ & 4.45 & 68.15 & $1,322.97$ & $2,952.87$ & $1,629,90$ \\
\hline 8 & 14.98 & 192.37 & 0 & 0 & 68.15 & 275.49 & 0 & $-275,49$ \\
\hline 9 & 0 & 9.75 & 0 & 0 & 68.15 & 77.90 & 0 & -77.90 \\
\hline 10 & 0 & 9.75 & 0 & 0 & 68.15 & 77.90 & 0 & -77.90 \\
\hline 11 & 0 & 9.75 & 0 & 0 & 68.15 & 77.90 & 0 & -77.90 \\
\hline 12 & 0 & 9.75 & 0 & 0 & 68.15 & 77.90 & 0 & -77.90 \\
\hline 13 & 0 & 9.75 & 0 & 0 & 68.15 & 77.90 & 0 & -77.90 \\
\hline 14 & 0 & 9.75 & $1.160,37$ & 3.67 & 68.15 & $1,241.94$ & $2,657.58$ & $1,415.64$ \\
\hline Total & 134.80 & 935.07 & $2,400.99$ & 113.74 & $1,022.25$ & $4,606.83$ & $5,610.45$ & $1,003.62$ \\
\hline$\overline{\text { NPV }}$ & $\$ 40.26 \mathrm{ha}^{-1}$ & NPV & $\$ 0.19 \mathrm{~m}^{3}$ & & & & & \\
\hline $\mathbf{B} / \mathbf{C}$ & 1,01 & EPV & $\$ 0.08 \mathrm{~m}^{3}$ & & & & & \\
\hline IRR & $6,38 \%$ & roduction Cost & $\$ 13.51 \mathrm{~m}^{3}$ & & & & & \\
\hline EPV & $\$ 16.80 \mathrm{ha}^{-1}$ & & & & & & & \\
\hline
\end{tabular}

Tabela 1 - Composição dos custos para preparo de área, plantio, colheita e transporte, máquinas, custos da terra, custos totais, receitas e fluxo de caixa. 
aid of the@RISK software. The program makes use of the Monte Carlo method for random variables. The input variables considered were costs and revenues, for the wood and charcoal production. Ten thousand interactions were performed on the input data, with normal distribution of data with variations between -10 and $+10 \%$ in costs and revenues, a percentage considered sufficient for project evaluation, according to the VPE parameter, which allows projects comparing with different durations.

\section{RESULTS}

\subsection{Eucalypt forest}

Wood harvesting and transporting were the main costs of wood production, representing $52 \%$ of the total. Land cost represented $22 \%$ of the total and those related to planting activities $20 \%$ (Table 1 ).

Cash flow was positive only in the years 7 and 14 , due to the wood sale, which minimized costs over the years and allowed the project to be economically viable, with NPV of $\$ 40.26 \mathrm{ha}^{-1}$ and EPV of $\$ 16.80$ $\mathrm{ha}^{-1}$. The wood production average cost found was $\$ 13.51 \mathrm{~m} 3$ wood $^{-1}$ (Tabela 1).

Risk analysis, with a input data (costs and revenues) variation of -10 to $10 \%$, presented minimum and maximum EPV values of \$-585.74 ha $^{-1}$ and $\$ 598.84 \mathrm{ha}^{-1}$ for wood production, that is, due to the cost and revenue variations, the project may remain economically viable or be unfeasible. Due to this variation, the probability of wood production being unviable was $50 \%$. The VPE mean value found in the risk analysis was $\$ 18.33 \mathrm{ha}^{-1}$. From $67 \mathrm{~km}$ of freight, the wood production becomes economically unfeasible.

\subsection{Charcoal production}

Charcoal production was analyzed separately from the wood production. In wood production, 2 cutting cycles were considered and 10 years in charcoal production, which is the useful life of the kilns. The charcoal annual production was $1,086.50$ mdc. The costs related to the wood purchase, land cost and charcoal transportation accounted for $81.98 \%$ and the labor costs and area preparation were $15.52 \%$ of the total (Table 2).

Cash flow was positive from the second year onwards, due to the charcoal sale. The lower cash flow in the first year compared to the others, is justified by the lower charcoal production, due to the kiln time construction. The charcoal production was economically viable, with NPV of $\$ 5.93 \mathrm{mdc}$ charcoal $^{-1}$ and EPV OF $\$ 4.71$ mdc charcoal $^{-1}$ (Table 2).

Risk analysis, with a input data (costs and revenues) variation of -10 to $10 \%$, presented minimum and maximum EPV values of $-\$ 7.60 \mathrm{mdc} \mathrm{CV}^{-1}$ and $\$ 233.90 \mathrm{mdc} \mathrm{CV}^{-1}$ for charcoal production, that is, due

Table 2 - Composition of labor costs, kiln and furnace construction, wood purchase, transport, total cost, revenue and cash flow of charcoal production.

Tabela 2 - Custos com mão de obra, construção do forno e da fornalha, compra de madeira, custo da terra, transporte, custos totais, receitas da venda de carvão vegetal e fluxo de caixa.

\begin{tabular}{|c|c|c|c|c|c|c|c|c|c|}
\hline$\overline{\text { Year }}$ & Labor & $\begin{array}{c}\text { Kiln } \\
\text { Construction }\end{array}$ & $\begin{array}{c}\text { Furnace } \\
\text { Construction }\end{array}$ & $\begin{array}{c}\text { Wood } \\
\text { Purchase }\end{array}$ & Land Cost & Transport & Total Cost & Revenues & CashFlow \\
\hline 0 & $7,771.77$ & $1,134.39$ & 661.82 & $12,436.12$ & 306.64 & $3,520.80$ & $25,831.54$ & $23,941.45$ & $-1,890.09$ \\
\hline 1 & $5,946.00$ & 113,44 & 53.20 & $24,872.23$ & 306.64 & $7,040.61$ & $38,332.12$ & $47,882.92$ & $9,550.80$ \\
\hline 2 & $5,946.00$ & 113,44 & 53.20 & $24,872.23$ & 306.64 & $7,040.61$ & $38,332.12$ & $47,882.92$ & $9,550.80$ \\
\hline 3 & $5,946.00$ & 113,44 & 53.20 & $24,872.23$ & 306.64 & $7,040.61$ & $38,332.12$ & $47,882.92$ & $9,550.80$ \\
\hline 4 & $5,946.00$ & 113,44 & 53.20 & $24,872.23$ & 306.64 & $7,040.61$ & $38,332.12$ & $47,882.92$ & $9,550.80$ \\
\hline 5 & $5,946.00$ & 113,44 & 53.20 & $24,872.23$ & 306.64 & $7,040.61$ & $38,332.12$ & $47,882.92$ & $9,550.80$ \\
\hline 6 & $5,946.00$ & 113,44 & 53.20 & $24,872.23$ & 306.64 & $7,040.61$ & $38,332.12$ & $47,882.92$ & $9,550.80$ \\
\hline 7 & $5,946.00$ & 113,44 & 53.20 & $24,872.23$ & 306.64 & $7,040.61$ & $38,332.12$ & $47,882.92$ & $9,550.80$ \\
\hline 8 & $5,946.00$ & 113,44 & 53.20 & $24,872.23$ & 306.64 & $7,040.61$ & $38,332.12$ & $47,882.92$ & $9,550.80$ \\
\hline 9 & $5,946.00$ & 113,44 & 53.20 & $24,872.23$ & 306.64 & $7,040.61$ & $38,332.12$ & $47,882.92$ & $9,550.80$ \\
\hline Total & $61,285.77$ & $2,155.35$ & $1,140.62$ & $236,286.19$ & $3,066.40$ & $66,886.29$ & $370,820.62$ & $454,887.73$ & $84,067.11$ \\
\hline $\mathrm{B} / \mathrm{C}$ & 1,59 & NPV & $\$ 5.93 \mathrm{mdc} \mathrm{CV}^{-1}$ & & & & & & \\
\hline IRR & $52 \%$ & EPV & $\$ 50,022.00$ & & & & & & \\
\hline NPV & $\$ 63,064.71$ & EPV & $\$ 4.71 \mathrm{mdc} \mathrm{CV}^{-1}$ & & & & & & \\
\hline
\end{tabular}

Revista Árvore 2021;45:e4539 
to costs and revenues variations, charcoal production may become unfeasible with a probability of $10 \%$. The EPV average value found in the risk analysis was $\$ 9.80 \mathrm{mdc} \mathrm{CV}^{-1}$. The sensitivity analysis also allowed us to assess that charcoal production is economically viable, under the conditions evaluated, from the price of $\$ 39,18 \mathrm{mdc} \mathrm{CV}^{-1}$.

\section{DISCUSIONS}

The Brazilian total area of commercial forests is 7.83 million hectares and eucalypt plantations represent $72.80 \%$ of the total, mainly for the cellulose industry and charcoal production. Minas Gerais State is the main eucalypt producer in the country, with $21.77 \%$ of the entire area (IBÁ, 2020) and, assessing how costs and revenues affect your economic viability is important, since in this project type the revenue comes, usually, from the wood sale in the last year.

Eucalypt forest implementing costs vary from region to region, depending on input and labor costs, which are those that can compromise the eucalypt planting economic viability (Rezende et al., 2006). The implantation cost found in the present study was $\$ 884.18 \mathrm{ha}^{-1}$ and the wood sale by $\$ 13.51 \mathrm{~m}^{3}$ made the project viable, with NPV of $\$ 40.26 \mathrm{ha}^{-1}$ and EPV of $\$ 16.80 \mathrm{ha}^{-1}$. In another study, Eucalypt production was economically unfeasible, with and without land cost consideration, with NPV of $-\$ 865.92 \mathrm{ha}^{-1}$ and $-\$ 1,182.92 \mathrm{ha}^{-1}$, respectively, at an interest rate of $6 \%$ year (Queiroz and Silva, 2016). The authors found that the implantation cost $\left(\$ 1,077.13 \mathrm{ha}^{-1}\right)$ and wood standing sale revenue ( $\left.\$ 808.92 \mathrm{ha}^{-1}\right)$, marketed to $\$ 2.84 \mathrm{~m}^{3}$, were not sufficient to offset the negative cash flow.

The sensitivity analysis in the present study, in wood production, allowed to evaluate that, due to the implementation costs in the early years, variations in revenue from the wood sale made it economically unfeasible. The negative cash flow in the first years was not always offset by the wood sale revenue in the last year.

The kiln-furnace system, in addition to being environmentally better than traditional charcoal production systems, due to the methane burning, has technical advantages (Ribeiro et al., 2020). In addition to being economically viable, the kiln-furnace system has other advantages, when compared to traditional kiln, such as greater gravimetric yield (Ribeiro et al., 2020). Wood consumption, when comparing the kilnfurnace system with the "hot tail" type was $20 \%$ lower, for the same amount of charcoal production, which resulted in better cash flow and better economically results, with profitability $16.4 \%$ higher (Oliveira et al., 2014).

The carbonizations number using the kiln-furnace system, according to the same authors, it is also smaller to traditional kilns which, in addition to the lower wood consumption, it reduces the carbonizers labor costs. The carbonizations, when comparing the kilnfurnace system with the "hot tail" kiln type, was $20 \%$ lower, for the same amount of charcoal production, which resulted in a $17.88 \%$ lower expense with the wood purchase (Oliveira et al., 2014).

Charcoal production in innovative systems is dependent on a higher GY when compared to conventional methodologies, to be more attractive to rural producers, since it has implantation costs higher than traditional kilns (Protasio et al., 2021). When comparing the charcoal production in "hot-tail" kilns with metallic cylinder kilns, the most innovative layout showed better economic viability, with higher NPV, despite the higher implantation cost, due to the better GY. The metallic cylinder kiln Pay Back was 3.09 years, higher than the 2.93 years observed for the "hot tail" (Silva et al., 2014).

The charcoal production sensitivity analysis, for all the interactions carried out, it remained economically viable, because the charcoal sale revenues were higher than the costs, in all scenarios. The wood purchasing costs, charcoal transporting and labor are the ones that most negatively influence the NPV, with a negative correlation. Furnace and kiln construction are the costs that least influence the NPV. Sensitivity analysis is an important tool to show how changes in costs and revenues impact the project economic analysis, however, project economic viability in the forestry is subject to unforeseen risks such as adverse weather, pests, diseases and other natural hazards that can reduce productivity and substantially affect results (Martinelli et al., 2019).

Economic analysis per wood unit produced (NPV of $\$ 0.19 \mathrm{~m}^{3} \mathrm{ha}^{-1}$ and EPV of $\$ 0,08 \mathrm{~m}^{3} \mathrm{ha}^{-1}$ ), with production cost of $\$ 13.51 \mathrm{~m}^{-3}$ and sold to $\$ 14.20 \mathrm{~m}^{-3}$, shows that changes in production costs can make the

\author{
Revista Árvore 2021;45:e4539
}


business economically unfeasible. The probability of wood production economic unfeasibility was 50\%, due to the proximity of the values between costs and revenues. Charcoal, due to the price increase in recent years, has become more attractive to the producer, with favorable indicators in relation to the wood production (NPV of $\$ 5.93 \mathrm{mdc}^{-1}$ and EPV of $\$ 4.71 \mathrm{mdc}^{-1} \mathrm{CV}^{-1}$ ). Due to the fact that revenues are higher than the costs of charcoal production, and the product's commercialization price, the economic unfeasibility probability was $10 \%$.

Wood and charcoal price, interest rate, planning horizon and production costs, must be taken into account in the economic analysis of forestry projects, which, if not properly planned and executed, may be economically unfeasible.

\section{CONCLUSIONS}

Eucalypt wood and charcoal production is economically viable in the region of Lamim, in Minais Gerais State.

The wood production probability economic unfeasibility is $50 \%$.

The charcoal production probability economic unfeasibility is $10 \%$.

The wood production economic viability is more impacted by the costs and revenues variation, due to the fact that the production cost is only $4.84 \%$ lower than the wood sale value. In the case of charcoal production, economic viability is less impacted by changes in values, since revenues are much higher than costs.

Wood purchase costs are the main costs in the wood and charcoal production.

The charcoal producing economic feasibility using the kiln-furnace system is important to encourage the adoption of this new technology and encourage sustainable steelmaking in the country.

\section{AUTHOR CONTRIBUTIONS}

Bruno L. S. Schettini: data analyse and text writen, Laércio A. G. Jacovine: research superfision and text review, Carlos M. M E. Torres: conception and data analyse, Angélica C. O. Carneiro: technical review, Paulo H. Villanova: text review, Samuel J. S.
S. da Rocha: text review, Maria P. M. X. Rufino: text review, Renato V. O. Castro: technical review.

\section{REFERENCES}

Cardoso MT, Damásio RAP, Carneiro ACO, Jacovine LAG, Vital BR, Barcelos DC. Construction of a gas burning system resulting from carbonization to reduce pollutants emissions. Cerne. 2010;16(1):115124.

Costa ACPR, Ramalho FMG, Costa LR, Trugilho PF, Hein PRG. Classification of commercial charcoal for domestic use by near infrared spectroscopy. Biomassa and Bioenergy. 2019;127:105280. doi:10.1016/j.biombioe.2019.105280

INDÚSTRIA BRASILEIRA DE ÁRVORES IBÁ. O setor brasileiro de florestas plantadas. 2020 [cited 2020 Apr 23]. Available from: https://iba.org/ datafiles/publicacoes/relatorios/relatorio-iba-2020. pdf

Martinelli GC, Schlindwen MM, Padovan MP, Gimenes RMT. Decreasing uncertainties and reversing paradigms on the economic performance of agroforestry systems in Brazil. Land Use Policy. 2019;80:274-286. doi: 10.1016/j. landusepol.2018.09.019

Organização das Nações Unidas Brasil — ONU. Siderurgia Sustentável desenvolve cadeia de produção com baixa emissão de poluentes. 2018 [cited 2020 Sep 23]. Available from: https:// nacoesunidas.org/siderurgia-sustentavel-desenvolvecadeia-de-producao-com-baixa-emissao-poluentes/

Oliveira AC, Carneiro ACO, Barcellos DC, Rodriguez AV, Amaral BMN, Pereira BLC. Artificial cooling in rectangular kilns for chacoal production. Revista Árvore. 2015;39(4):769-778. doi: 10.1590/0100-67622015000400020

Oliveira AC, Carneiro ACO, Pereira BLC, Vital BR, Carvalho AMML, Trugilho PF, et al. Optimization of charcoal production through control of carbonization temperatures. Revista Árvore. 2013;37(3):557-566. doi: 10.1590/S0100-67622013000300019

Oliveira AC, Pereira BLC, Salles TT, Carneiro ACO, Lana AQ. Economic risk analysis of two systems of charcoal production. Floresta e Ambiente. 2017;24:111. doi: 10.1590/2179-8087.026516 
Oliveira AC, Salles TT, Pereira BLC, Carneiro ACO, Braga CS, Santos RC. Viabilidade econômica da produção de carvão vegetal em dois sistemas produtivos. Floresta. 2014;44(1):143-152. doi: 10.5380/rf.v44i1.32043

Protasio TP, Lima MDR, Scatolino MV, Silva AB, Figueiredo ICR de, Hein PRG, et al. Charcoal productivity and quality parameters for reliable classification of Eucalyptus clones from Brazilian energy forests. Renewable Energy. 2021;164:34-45. doi: 10.1016/j.renene.2020.09.057

Queiroz AM de, Silva ZAGPG. Aspectos econômicos dos plantios com eucalipto (Eucalyptus spp.) na região do baixo acre. Floresta. 2016,46(3):287-296. doi: $10.5380 /$ rf.v46i3.42931

Rezende JLP, Oliveira AD. Análise econômica e social de projetos florestais. $3^{\mathrm{a}}$. ed. Viçosa: Editora UFV; 2013. ISBN 9788572694674

Rezende JLP, Padua CTJ, Oliveira AD de, Scolforo JRS. Economic analysis of forest fomentation with eucalyptus in the state of Minas Gerais. Cerne. 2006;12(3):221-231.

Ribeiro GBD, Carneiro ACO, Lana AQ, Valverde SR. Economic viability of four charcoal productive systems from Minas Gerais state. Revista Árvore. 2020;44:1-11. doi: 10.1590/1806-908820200000001

Rolim SG, De Camargo PBM, Lania GD, De Moares LFJ. Climatic classification of Köppen and Thornthwaite sistems and their applicability in the determination of agroclimatic zonning for the state of São Paulo, Brazil. Bragantia. 2007;66(4):711-720. doi: 10.1590/S0006-87052007000400022

Serviço Brasileiro de Apoio às Micro e Pequenas Empresas - Sebrae. Normas sindicais e encargos sociais e trabalhistas. 2015 [cited 2021 May 26]. Available from: https://www.sebrae.com.br/sites/ PortalSebrae/bis/normas-sindicais-e-encargossociais-e-trabalhistas,9fff2eb935bcb410VgnVCM10 00003b74010aRCRD

Silva DAL, Cardoso EAC, Varanda LD, Christoforo AL, Malinovski RA. Economic feasibility study of three charcoal production systems using different methods. Revista Árvore. 2014;38(1):185-193. doi: 10.1590/S0100-67622014000100018

Vilela AO, Lora ES, Quintero QR, Vicintin RA, Souza TPS. A new technology for the combined production of charcoal and electricity through cogeneration. Biomass and Bioenergy. 2014;69:222240. doi: 10.1016/j.biombioe.2014.06.019

Yang Y, Song G, LU S. Assessment of land ecosystem health with Monte Carlo simulation: A case study in Qiqihaer, China. Journal of Cleaner Production. 2020;250: 119522. doi: 10.1016/j. jclepro.2019.119522

Zarony H, Maciel LB, Carvalho DB, Pamplona EO. Monte Carlo Simulation approach for economic risk analysis of an emergency energy generation system. Energy. 2019;172:498-508. doi: 10.1016/j. energy.2019.01.145 